\title{
A Prenylated Flavonoid from the Methanol Fraction of Breadfruit Root (Artocarpus communis)
}

\section{Kristina Damiyanti, Ari Widiyantoro \& *Rudiyansyah}

Kimia/FMIPA- Universitas Tanjungpura, Pontianak-Indonesia 78115

Received 22 September 2020, Revised 23 October 2020, Accepted 23 November 2020

doi: 10.22487/j24775185.2020.v9.i4.pp237-244

\begin{abstract}
Breadfruit (Artocarpus communis) is a tropical fruit plant that belongs to the genus Artocarpus of the Moraceae family. Prenylated flavonoid compounds were isolated from the methanol fraction of breadfruit root wood using maceration, partitioning, and chromatography methods, while characterization was carried out through phytochemical tests and ${ }^{1} H-N M R$ spectrum data analysis. The $K_{I} D_{2}\left(P_{1}\right)$ compound obtained was a yellow solid with a mass of $5 \mathrm{mg}$. The phytochemical test of the $K_{1} D_{2}\left(P_{1}\right)$ compound gave positive results for the flavonoid group. The ${ }^{1} \mathrm{H}-\mathrm{NMR}$ spectrum data $\left(\mathrm{CDCl}_{3}, 500 \mathrm{MHz}\right)$ of compound $\mathrm{K}_{1} \mathrm{D}_{2}\left(P_{1}\right)$ showed a typical chemical shift at $\delta_{H} 13.42(1 \mathrm{H}, \mathrm{s}, 5-\mathrm{OH})$ for the hydroxy groups associated with carbonyl; $7.68\left(1 \mathrm{H}, \mathrm{d}, J=8.5 \mathrm{~Hz}, \mathrm{H}-\mathrm{C}^{\prime}\right)$; $6.71(1 \mathrm{H}, d d, J=16.0 ; 7.1 \mathrm{~Hz}, \mathrm{H}-10) ; 6.56(1 \mathrm{H}, \mathrm{d}, J=16.0 \mathrm{~Hz}, \mathrm{H}-9) ; 6.54(1 \mathrm{H}, d d, J=8.5 ; 1.8 \mathrm{~Hz}, \mathrm{H}-5$ '); $6.46(1 \mathrm{H}, \mathrm{s}, \mathrm{H}-3) ; 6.42\left(1 \mathrm{H}, d, J=1.8 \mathrm{~Hz}, \mathrm{H}-3{ }^{\prime}\right) ; 6.26(1 \mathrm{H}, d, J=9.3 \mathrm{~Hz}, \mathrm{H}-14) ; 5.42(1 \mathrm{H}, d, J=9.3$ $\mathrm{Hz}, \mathrm{H}-15) ; 3.94\left(3 \mathrm{H}, \mathrm{s}, \mathrm{2}^{\prime}-\mathrm{OCH}_{3}\right) ; 2.47(1 \mathrm{H}, \mathrm{m}, \mathrm{H}-11) ; 1.97(3 \mathrm{H}, \mathrm{s}, \mathrm{H}-17) ; 1.69(3 \mathrm{H}, \mathrm{s}, \mathrm{H}-18)$, and 1.10 $(6 H, d, J=6.7 \mathrm{~Hz}, \mathrm{H}-12$ and $\mathrm{H}-13)$. Based on the results of phytochemical tests and analysis of ${ }^{1} \mathrm{H}-\mathrm{NMR}$ spectrum data compared with literature data, it showed that the isolated $K_{1} D_{2}\left(P_{1}\right)$ compound is 4', 5-dihydroxy-

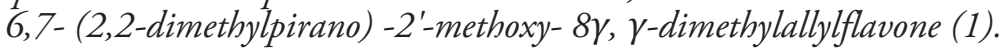

Keywords: Artocarpus communis, flavonoid, prenylation, phytochemistry

\section{Pendahuluan}

Artocarpus merupakan genus yang kaya akan senyawa fenolik khususnya kalkon, flavonoid, santon, arilbenzofuran, dan stilbenoid (Jagtap \& Bapat, 2010; Erwin, 2010; Hakim, 2010). Golongan flavonoid merupakan senyawa yang dominan ditemukan dari tanaman Artocarpus (Hakim, 2010). Beberapa senyawa yang terkandung di dalam genus Artocarpus diketahui memiliki aktivitas biologis dan telah digunakan untuk pengobatan radang, malaria, demam, diare, diabetes, dan infeksi cacing pita (Jagtap \& Bapat, 2010). Salah satu spesies Artocarpus yang telah diteliti sebelumnya adalah sukun (Artocarpus communis).

Tanaman sukun merupakan tanaman buah tropis yang banyak terdapat di Indonesia. Menurut Tzeng, dkk., (2014) tanaman sukun telah digunakan dalam pengobatan tradisional untuk menyembuhkan sirosis hati, hipertensi, dan diabetes.

Secara tradisional, daun sukun telah digunakan untuk menyembuhkan penyakit kulit, jantung, ginjal, radang, dan demam (Kristanti dan Tunjung, 2015; Hariana, 2006). Ekstrak dietil eter dari kayu batang sukun telah dimanfaatkan sebagai obat kanker payudara (Arung, dkk., 2009) sedangkan kulit buah sukun digunakan dalam pengobatan tradisional untuk melancarkan ASI (Hariana, 2006). Buah sukun digunakan sebagai makanan sehat bagi penderita diabetes, bunga sukun digunakan sebagai obat sakit gigi, dan kulit batang sukun dimanfatkan untuk pengobatan radang sehingga sering digunakan untuk mengatasi luka lambung (Heyne, 1987). Selain itu ekstrak aqueous dari kulit akar sukun juga telah digunakan sebagai obat diare, disentri, dan diabetes melitus (Adewole \& Ojewole, 2007).

Berdasarkan beberapa penelitian sebelumnya, kandungan metabolit sekunder dari tanaman sukun yang tumbuh di beberapa daerah telah dilaporkan. Hsu, dkk., (2012) berhasil mengisolasi senyawa arcommunol $\mathrm{C}$, arcommunol $\mathrm{D}$, dan arcommunol $\mathrm{E}$ pada daun sukun yang berasal dari Taiwan. Kuete, dkk., (2011) berhasil mengisolasi senyawa artonin $\mathrm{E}$ dan 2-[3,5dihidroksi)-(Z)-4-(3-methylbut-1enyl) phenyl] benzofuran-6-ol pada kulit batang sukun yang berasal dari Nkolbisson, wilayah Kamerun. Lin, dkk., (2009) mengidentifikasi dua flavonoid terprenilasi yaitu senyawa siklogerakomunin dan artoflavon A pada akar sukun yang berasal dari Kaohsiung Hsien, Taiwan. Toume, dkk., (2014) mengisolasi senyawa flavonoid terprenilasi

*Correspondence:

Rudiyansyah

e-mail: rudiyansyah@chemistry.untan.ac.id

(c) 2020 the Author(s) retain the copyright of this article. This article is published under the terms of the Creative Commons Attribution License 4.0, which permits unrestricted non-commercial use, distribution, and reproduction in any medium, provided the original work is properly cited. 
Pannokin D, E, F, dan G pada akar sukun yang berasal dari Khon Kaen, Thailand. Chan, dkk., (2003) mengidentifikasi artocommunol CA, artocommunol $\mathrm{CB}$, artocommunol CC, artocommunol CD, dan artocommunol $\mathrm{CE}$ pada kulit akar sukun.

Salah satu bagian dari tanaman sukun yang belum dilaporkan kandungan metabolit sekundernya adalah kayu akar. Heyne (1987) menyebutkan bahwa dalam pengobatan tradisional, air rebusan kayu akar sukun dapat diminum untuk menghentikan murus darah. Tulisan ini dimaksudkan untuk mendeskripsikan kandungan senyawa metabolit sekunder khususnya flavonoid pada kayu akar sukun yang berasal dari daerah Pontianak, Kalimantan Barat.

\section{Metode}

Alat yang digunakan adalah gelas laboratorium, kolom kromatografi cair vakum $(\mathrm{KCV})$, kolom kromatografi kolom gravitasi (KKG), chamber, lampu UV $\left(\lambda_{254}\right.$ dan $\left.\lambda_{366} \mathrm{~nm}\right)$, peralatan maserasi, pipa kapiler, plat tetes, peralatan destilasi (thermo scientific), pompa vakum, rotary vacuum evaporator (Heidolph), spektrometer Nuclear Magnetic resonance (Agilent $500 \mathrm{MHz}$ ), dan spektrometer massa. Bahan yang digunakan adalah kayu akar sukun (A. communis), etil asetat, kloroform, metanol, $n$-heksana, kertas saring, pereaksi uji fitokimia besi (III) klorida 5\% dan pereaksi Shinoda, plat alumunium 20x20 cm silika gel $60 \mathrm{~F}_{254}$ Merck, silika gel G60, silika gel Merck G 60 (230-400 mesh), dan serium sulfat 5\%.

Kayu akar sukun ( $A$. communis) diambil dari daerah Pontianak, Kalimantan Barat. Sampel sebanyak 2,1 kg dibersihkan dari kulit akar sukun, dipotong-potong, dan dikeringkan tanpa terpapar sinar matahari secara langsung. Sampel yang telah kering kemudian diserbukkan dengan mesin pencacah di Workshop of Wood Fakultas Pertanian Universitas Tanjungpura.

\section{Ekstraksi dan Partisi}

Serbuk kayu akar sukun (A. communis) sebanyak 2,1 kg dimaserasi dalam metanol selama 3 x 24 jam pada suhu ruang. Maserat disaring untuk memisahkan residu dan filtrat. Semua filtrat hasil maserasi digabungkan dan dipekatkan dengan rotary vacuum evaporator pada suhu $40^{\circ} \mathrm{C}$ sehingga diperoleh crude ekstrak metanol dan disimpan dalam botol coklat tertutup.

Crude ekstrak metanol dilarutkan dalam 200 $\mathrm{mL}$ metanol lalu dipartisi dengan $n$-heksana sebanyak $3 \times 150 \mathrm{~mL}$, sehingga diperoleh fraksi $n$ heksana dan fraksi metanol. Semua fraksi dipekatkan dengan rotary vacuum evaporator kemudian disimpan dalam botol masing-masing setelah ditimbang.

\section{Uji fitokimia}

Secara umum analisis fitokimia dilakukan untuk mengidentifikasi golongan metabolit sekunder yang terkandung dalam suatu sampel. Pada penelitian ini analisis ditujukan khusus untuk golongan flavonoid dan fenolik. Uji terhadap flavonoid dilakukan dengan menambahkan serbuk $\mathrm{Mg}$ dan $\mathrm{HCl}$ pekat (pereaksi Shinoda). Hasil positif ditandai dengan munculnya warna merah, kuning, atau jingga (Harborne, 1987). Uji terhadap golongan fenolik dilakukan dengan menambahkan reagen $\mathrm{FeCl}_{3}$ 5\% dan hasil positif ditandai dengan terbentuknya warna hijau, merah, ungu, biru, hitam, atau coklat (Harborne, 1987).

\section{Kromatografi lapis Tipis (KLT)}

Secara kualitatif metode ini dilakukan untuk mengidentifikasi kompleksitas senyawasenyawa yang terkandung dalam suatu ekstrak. Fraksi metanol ditotolkan dengan pipa kapiler di atas plat alumunium KLT silica gel G $60 \mathrm{~F}_{254}$ (jarak elusi $3,5 \mathrm{~cm}$ ), kemudian dielusi dalam chamber dengan fase gerak dengan tingkat kepolaran yang berbeda. Penampakan noda pada plat alumunium KLT berturut-turut dilihat di bawah lampu UV $\bigotimes_{254}$ dan $\bigotimes_{366} \mathrm{~nm}$, disemprot dengan serium sulfat 5\%, lalu dipanaskan.

\section{Kromatografi Cair Vakum (KCV)}

Metode ini dan kromatografi kolom gravitasi (KKG) secara umum digunakan untuk memfraksinasi suatu ekstrak menjadi fraksi-fraksi yang lebih sederhana. Fraksi metanol sebanyak 17 gram diimpregnasi dengan rasio 3:1 (sampel/silika) menggunakan silica gel $60(0,2-0,5 \mathrm{~mm})$ sampai homogen dan kering. Fase diam silica gel G60 dimasukkan dalam kolom $\mathrm{KCV}$ diameter $10 \mathrm{~cm}$ sambil divakum sehingga padat lalu dielusi dengan eluen $n$-heksana 100\%. Fraksi metanol terimpregnasi dimasukkan di atas permukaan fase diam pada kolom KCV. Proses elusi dilakukan secara bergradien dimulai dari $n$-heksana:etil asetat $(7: 3),(6: 4),(1: 1),(4: 6),(3: 7)$, dan (1:9), etil asetat $100 \%$, dan metanol 100\%. Eluat ditampung sehingga diperoleh 18 botol. Profil 18 eluat hasil KCV dianalisis menggunakan plat KLT. Pola noda yang mirip digabungkan sehingga diperoleh 8 fraksi gabungan (K1-K8) lalu dilanjutkan ke tahap analisis fitokimia terhadap kandungan fenolik dan flavonoid 
untuk semua fraksi. Fraksi K1 dipilih dan dilanjutkan ke tahap kromatografi kolom gravitasi (KKG).

\section{Kromatografi Kolom Gravitasi (KKG)}

$128 \mathrm{mg}$ Fraksi K1 diimpregnasi dengan menggunakan silica gel $60(0,2-0,5 \mathrm{~mm})$ sampai homogen dan kering. Fase diam silica gel Merck G 60 (230-400 mesh) dimasukkan dalam kolom dengan cara basah (silika dalam $n$-heksana). Fraksi K1 terimpregmasi dimasukan di atas permukaan fase diam dan dielusi secara gradien dimulai dari eluen $n$ heksana:etil asetat; (8:2), (6:4), (1:1), (4:6), (2:8), etil asetat $100 \%$, dan metanol $100 \%$. Eluat hasil KKG ditampung ke dalam botol vial masing-masing $5 \mathrm{~mL}$ sehingga diperoleh 243 botol, kemudian semua dianalisis KLT. Pola noda yang mirip digabungkan sehingga diperoleh 13 fraksi dengan kode $K_{1} D_{1}$ $\mathrm{K}_{1} \mathrm{D}_{13}$, lalu semua fraksi analisis fitokimia terhadap fenolik dan flavonoid. Fraksi $\mathrm{K}_{1} \mathrm{D}_{2}$ dipilih dan dilanjutkan ke tahap kromatografi lapis tipis preparatif (KLTP).

\section{Kromatografi lapis Tipis Preparatif(KLTP)}

Metode ini secara umum digunakan untuk mengisolasi dan memurnikan senyawa dari fraksifraksi sederhana yang dihasilkan dari KCV dan KKG. Fraksi $\mathrm{K}_{1} \mathrm{D}_{2}$ ditotol segaris pada plat alumunium KLT $20 \times 20 \mathrm{~cm}$ dan dibiarkan beberapa saat sampai pelarutnya mengering. Fraksi $\mathrm{K}_{1} \mathrm{D}_{2}$ kemudian dielusi dengan fase gerak $n$-heksana:etil asetat $(9: 1)$. Pita noda yang terpisah-pisah dilihat di bawah lampu UV $\lambda_{254} \mathrm{~nm}$ dan ditandai dengan pensil. Tiga pita noda diambil dengan cara mengerok lapisan silika dan diberi kode $\mathrm{K}_{1} \mathrm{D}_{2}\left(\mathrm{P}_{1}\right)$, $\mathrm{K}_{1} \mathrm{D}_{2}\left(\mathrm{P}_{2}\right)$, dan $\mathrm{K}_{1} \mathrm{D}_{2}\left(\mathrm{P}_{3}\right)$. Masing-masing pita yang telah diambil dilarutkan dalam pelarut etil asetat lalu di saring. Ketiga senyawa tersebut dianalisis KLT dengan kombinasi fasa gerak eluen $n$-heksana:etil asetat (9:1) dan selanjutnya dianalisis fitokimia. Hasil analisis KLT 2-dimensi menggunakan eluen nheksana:etil asetat (8:2) dan kloroform: $n$-heksana (9:1) diketahui bahwa senyawa $\mathrm{K}_{1} \mathrm{D}_{2}\left(\mathrm{P}_{1}\right)$ sudah cukup murni dan positif mengandung senyawa golongan flavonoid. Senyawa $\mathrm{K}_{1} \mathrm{D}_{2}\left(\mathrm{P}_{1}\right)$ dilanjutkan ke tahap analisis dengan spektrometer ${ }^{1} \mathrm{H}-\mathrm{NMR}$.

Isolat $\mathrm{K}_{1} \mathrm{D}_{2}\left(\mathrm{P}_{1}\right)$ yang diperolah dari hasil pemisahan dan pemurnian dianalisis menggunakan spektrometer ${ }^{1} \mathrm{H}-\mathrm{NMR} 500 \mathrm{MHz}$. Analisis NMR dilakukan dengan mengirim isolat ke laboratorium NMR FMIPA Institut Teknologi Bandung (ITB), Bandung.
Hasil dan Pembahasan

\section{Preparasi Kayu akar sukun (A. communis)}

Kayu akar sukun diperoleh dari daerah Pontianak, Kalimantan Barat yaitu pada titik koordinat 001'51" S dan 109¹8'04”E. Kayu akar sukun yang segar dikumpulkan dan dibersihkan dari kulitnya. Kayu akar sukun dipotong-potong dan dikeringkan tanpa terpapar sinar matahari secara langsung agar tidak merusak metabolit sekunder yang terdapat dalam kayu akar sukun (artefak). Sampel kering diserbukkan dengan tujuan untuk memperluas luas permukaan sampel pada saat dilakukan maserasi, sehingga senyawa metabolit sekunder dapat terekstraksi secara optimal.

\section{Ekstraksi Serbuk Kayu akar sukun (A. communis)}

2,1 kg serbuk kayu akar sukun diekstraksi dengan cara maserasi $3 \times 24$ jam. Maserasi serbuk kayu akar sukun dilakukan menggunakan pelarut metanol yang bersifat polar karena mampu memecahkan dinding sel tumbuhan sehingga sebagian besar senyawa metabolit sekunder terlarut dalam metanol. Maserat disaring menggunakan corong dan kertas saring. Maserat yang diperoleh sebanyak 20,0 gram (rendemen 1\% dari massa serbuk sampel) setelah dipekatkan menggunakan rotary vacuum evaporator pada suhu $40{ }^{\circ} \mathrm{C}$. Crude ekstrak metanol diuji fitokimia dan diketahui mengandung senyawa metabolit sekunder flavonoid dan fenolik.

\section{Partisi (ekstraksi cair-cair) Ekstrak Metanol}

Crude ekstrak metanol dipartisi dengan pelarut $n$-heksana untuk memisahkan fraksi nonpolar. Perlakuan ini diulang sebanyak tiga kali hingga diperoleh fraksi $n$-heksana berwarna pudar yang menandakan bahwa fraksi nonpolar telah terpisah secara maksimal. Fraksi $n$-heksana dan fraksi metanol yang dihasilkan kemudian dipekatkan dengan rotary vacuum evaporator sehingga diperoleh massa masing-masing 2,6 gram (rendemen 12,9\% dari massa crude ekstrak) dan 17,4 gram (rendemen $87,1 \%$ dari massa crude ekstrak).

\section{Uji fitokimia}

Analisis fitokimia dilakukan terhadap fraksi $n$-heksana dan fraksi metanol untuk mengidentifikasi adanya kandungan senyawa flavonoid dan fenolik. Uji flavonoid dilakukan dengan menambahkan pereaksi Shinoda (serbuk $\mathrm{Mg}$ dan $\mathrm{HCl}$ pekat) dengan hasil positif ditandai munculnya warna jingga sedangkan uji golongan fenolik dilakukan dengan menambahkan reagen $\mathrm{FeCl}_{3}$ 5\% yang memberikan 
hasil positif dengan terbentuknya warna hijau seperti dapat dilihat pada Gambar 1 dan Tabel 1.

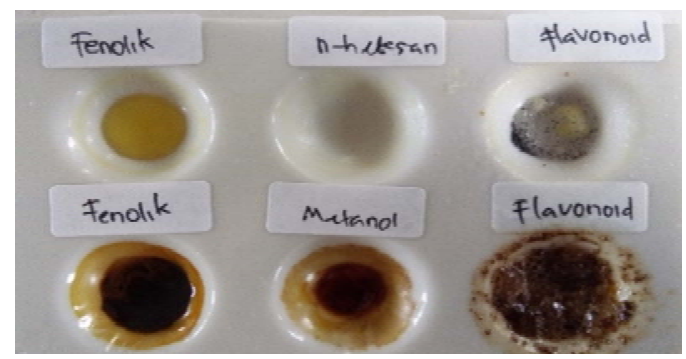

Gambar 1. Hasil uji fitokimia golongan fenolik dan flavonoid untuk fraksi metanol dan $n$-heksana

Tabel 1. Hasil uji fitokimia terhadap fraksi metanol dan fraksi $n$-heksana kayu akar sukun

\begin{tabular}{clcc}
\hline No & $\begin{array}{l}\text { Golongan } \\
\text { senyawa }\end{array}$ & $\begin{array}{c}{ }^{*} \text { Fraksi } \\
\text { metanol }\end{array}$ & $\begin{array}{c}\text { Fraksi } \\
n \text {-heksana }\end{array}$ \\
\hline 1 & Flavonoid & + & + \\
2 & Fenolik & + & - \\
\hline
\end{tabular}

Keterangan: (+) berubah warna spesifik, (-) tidak berubah

*Fraksi yang dilanjutkan ke tahap KCV

\section{Kromatografi Cair Vakum (KCV)}

Kromatografi cair vakum bertujuan untuk memisahkan campuran senyawa yang masih komplek pada ekstrak dengan cara mengeluarkan senyawa kimia secara bertahap dengan fase gerak bergradien dan bantuan pompa vakum. Sebelum proses $\mathrm{KCV}$, dilakukan pencarian beberapa variasi fase gerak dengan metode kromatografi lapis tipis (KLT).

Fraksi metanol ditotolkan pada beberapa plat KLT silica gel G $60 \mathrm{~F}_{254}$ (jarak elusi $3,5 \mathrm{~cm}$ ), kemudian masing-masing plat KLT dielusi dengan eluen kepolaran yang berbeda yaitu $n$-heksana:etil asetat; (7:3), (6:4), (1:1), (4:6), dan (3:7). Hasil orientasi KLT terhadap fraksi metanol ditunjukkan pada Gambar 2.

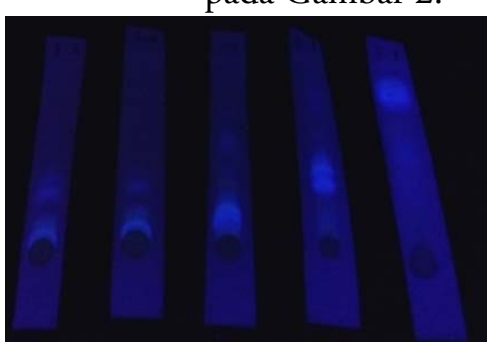

Gambar 2. Hasil orientasi KLT fraksi metanol dengan eluen n-heksana:etil asetat (a) 7:3 (b) 6:4 (c) 1:1 (d) 4:6, dan (e) 3:7; dilihat di bawah lampu UV $\lambda_{366} \mathrm{~nm}$

Berdasarkan hasil orientasi KLT pada Gambar 2, lima variasi fase gerak tersebut dapat digunakan pada proses KCV. Kolom KCV berdiameter $10 \mathrm{~cm}$ diisi dengan silika $60 \mathrm{G}$ dengan tinggi kurang lebih $6 \mathrm{~cm}$. Fraksi metanol terimpregnasi yang telah dimasukkan dalam kolom dielusi dengan fase gerak bergradien sehingga diperolah 18 sub-fraksi. Masing-masing sub-fraksi dianalisis KLT secara bersamaan dengan eluen $n$ heksana:etil asetat (4:6). Gambar 3. menunjukkan kromatogram KLT terhadap 18 sub-fraksi hasil $\mathrm{KCV}$.

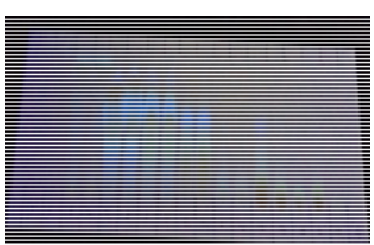

Gambar 3. Kromatogram KLT hasil KCV dari fraksi metanol dengan eluen $n$-heksana:etil asetat (4:6) (dilihat dengan bantuan lampu (a) UV $\lambda_{254} \mathrm{~nm}$, (b) UV $\lambda_{366} \mathrm{~nm}$ ) 
Berdasarkan hasil KLT tersebut, pola noda yang mirip digabungkan sehingga diperoleh 8 subfraksi gabungan (K1-K8). Semua sub-fraksi tersebut di KLT kembali dengan eluen nheksana:etil asetat (4:6). Pola noda pada plat KLT dideteksi menggunakan lampu UV $\lambda_{254} \mathrm{~nm}$ seperti terlihat pada Gambar 4.

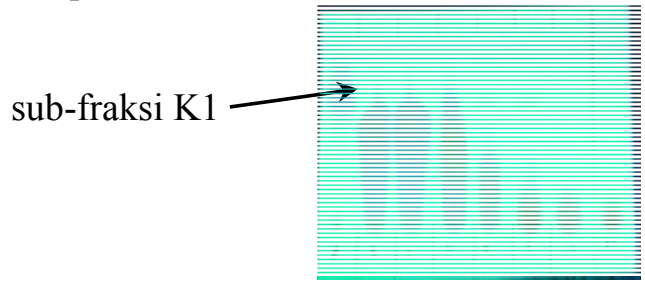

Gambar 4. Kromatogram KLT sub-fraksi K1-K8 hasil KCV di bawah sinar lampu UV $\lambda_{254} \mathrm{~nm}$

Semua sub-fraksi K1-K8 dianalisis fitokimia untuk golongan flavonoid dan fenolik.
Berdasarkan pola kromatogram pada Gambar 4 di atas, dipilih sub-fraksi K1 (128 mg) yang memberikan hasil positif terhadap pereaksi Shinoda dan $\mathrm{FeCl}_{3}$ 5\% selain dengan kompleksitas rendah. Fraksi lainnya tidak dipilih karena menunjukkan hasil negatif untuk flavonoid akan tetapi positif mengandung senyawa fenolik.

\section{Kromatografi Kolom Gravitasi (KKG)}

Sub-fraksi K1 (128 mg) difraksinasi dengan menggunakan metode KKG sehingga diperoleh 13 fraksi dengan kode $K_{1} D_{1}-K_{1} D_{13}$. Semua fraksi di KLT, dikeringanginkan pada suhu ruangan, serta di analisis fitokimia. Gambar 5. menunjukkan hasil KLT.

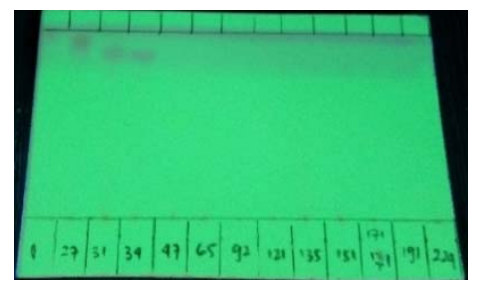

Gambar 5. Kromatogram KLT fraksi $\mathrm{K}_{1} \mathrm{D}_{1}-\mathrm{K}_{1} \mathrm{D}_{13}$ dengan eluen $n$-heksana:etil asetat (1:1) di bawah lampu UV $\lambda_{254} \mathrm{~nm}$

Fraksi $\mathrm{K}_{1} \mathrm{D}_{2}(26 \mathrm{mg})$ positif mengandung senyawa flavonoid berdasarkan hasil analisis fitokimia yang ditandai dengan munculnya warna kuning-jingga dan senyawa fenolik ditandai dengan adanya warna coklat kehitaman. Fraksi $\mathrm{K}_{1} \mathrm{D}_{2}$ dipilih untuk dilakukan pemurnian dengan KLT preparatif menggunakan eluen $n$-heksana:etil asetat (9:1). Elusi dilakukan sebanyak tiga kali hingga pola noda terpisah dengan baik.

\section{Kromatografi Lapis Tipis Preparatif (KLTP)}

Plat KLT-P yang digunakan dalam pemisahan senyawa flavonoid pada fraksi $\mathrm{K}_{1} \mathrm{D}_{2}$ berukuran $20 \times 20 \mathrm{~cm}$. Fraksi $\mathrm{K}_{1} \mathrm{D}_{2}$ ditotolkan sepanjang plat KLT kemudian dielusi dengan fasa gerak $n$-heksana:etil asetat (9:1). Gambar 6 menunjukkan hasil KLTP fraksi $\mathrm{K}_{1} \mathrm{D}_{2}$.

Pita-pita noda hasil elusi dilihat di bawah sinar lampu UV $\lambda_{254} \mathrm{~nm}$ untuk diberi tanda dan diambil dengan cara dikerok lalu dilarutkan dalam etil asetat dan di saring. Tiga isolat yang dihasilkan kemudian dilakukan analisis KLT dengan eluen $n$ heksana:etil asetat $(9: 1)$ dan dilakukan analisis fitokimia.

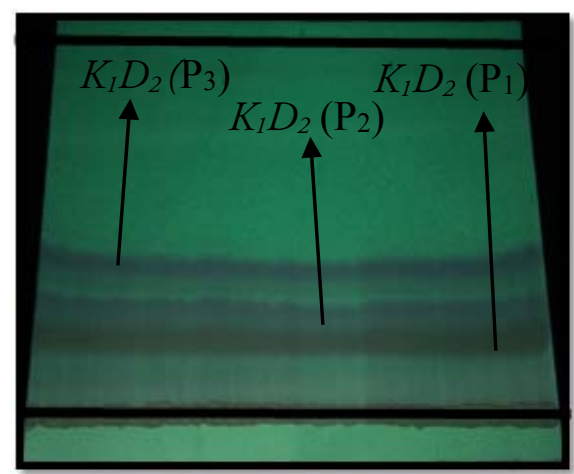

Gambar 6. Kromatogram KLT preparatif di bawah lampu UV $\lambda_{254} \mathrm{~nm}$

Hasil analisis fitokimia terhadap 3 isolat menunjukkan bahwa hanya isolat $\mathrm{K}_{1} \mathrm{D}_{2}\left(\mathrm{P}_{1}\right)$ positif mengandung senyawa flavonoid yang ditandai dengan terbentuknya warna kuning-jingga. Isolat $\mathrm{K}_{1} \mathrm{D}_{2}\left(\mathrm{P}_{1}\right)$ dikeringkan dan diperoleh serbuk kuning sebanyak $5 \mathrm{mg}$. Uji kemurnian isolat dilakukan dengan KLT 2 dimensi menggunakan fasa gerak yaitu $n$-heksana:etil asetat (8:2), nheksana:kloroform (1:1) seperti terlihat pada Gambar 7. 


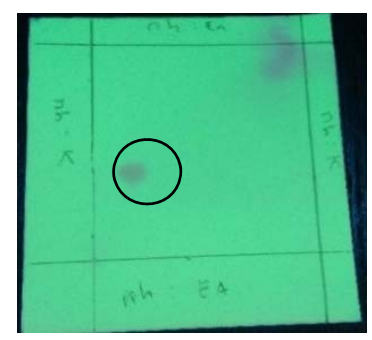

Gambar 7. Kromatogram KLT 2 dimensi isolat $\mathrm{K}_{1} \mathrm{D}_{2}\left(\mathrm{P}_{1}\right)$ fasa gerak; $n$-heksana:etil asetat (8:2) dan $n$-heksana:kloroform (1:1); ukuran plat KLT $5 \times 5$ cm; di bawah lampu UV $\lambda_{254} \mathrm{~nm}$

\section{Karakterisasi Senyawa Flavonoid Terhadap Isolat $K_{1} D_{2}\left(P_{1}\right)$ pada Kayu Akar Sukun}

Isolat $\mathrm{K}_{1} \mathrm{D}_{2}\left(\mathrm{P}_{1}\right)$ dilarutkan dalam kloroform$d\left(\mathrm{CDCl}_{3}\right)$ untuk analisis data spektrum proton menggunakan spektrometer NMR (Nuclear magnetic Resonance) pada frekuensi $500 \mathrm{MHz}(1 \mathrm{H})$. Spektrum ${ }^{1} \mathrm{H}-\mathrm{NMR} \quad\left(500 \quad \mathrm{MHz}, \quad\right.$ dalam $\left.\quad \mathrm{CDCl}_{3}\right)$ memperlihatkan sinyal yang khas pada geseran kimia $\delta_{\mathrm{H}} 13,42$ untuk gugus hidroksi yang terkelasi $(1 \mathrm{H}, \mathrm{s}$, $5-\mathrm{OH})$. Sinyal pada geseran kimia $\delta_{\mathrm{H}} 1,11$ dengan integrasi 6 proton dan konstanta kopling (/) 6,7 Hz untuk dua gugus metil $\left(\mathrm{CH}_{3}-17\right.$ dan $\left.\mathrm{CH}_{3}-18\right)$, dua geseran kimia pada $\delta_{\mathrm{H}} 6,71(1 \mathrm{H}, \mathrm{dd}, J=16,0 ; 7,1$
$\mathrm{Hz}, \mathrm{H}-10)$, dan $6,56(1 \mathrm{H}, \mathrm{d}, J=16,0, \mathrm{H}-9)$ untuk gugus allil dengan stereokimia trans, dan geseran kimia pada $\delta_{\mathrm{H}} 2,47(1 \mathrm{H}, \mathrm{m}, \mathrm{H}-11)$, keempat sinyal tersebut merupakan sinyal khas untuk gugus isoprenil (Hakim, dkk., 1998). Empat sinyal khas lainnya yaitu pada geseran kimia $\delta_{\mathrm{H}} 6,26(1 \mathrm{H}, \mathrm{d}, J=$ 9,3 Hz, H-14), 5,42 (1H, d, $J=9,3 \mathrm{~Hz}, \mathrm{H}-15), 1,97$ $(3 \mathrm{H}, \mathrm{s}, \mathrm{H}-17)$, dan 1,69 (3H, s, H-18) adalah untuk gugus dimetilpirano (Lathiff, dkk., 2015). Sinyal pada daerah aromatik dengan sistem $\mathrm{ABX}$ muncul pada geseran kimia $\delta_{\mathrm{H}} 6,42(1 \mathrm{H}, \mathrm{d}, J=1,8 \mathrm{~Hz}, \mathrm{H}$ $\left.3^{\prime}\right), 6,54\left(1 \mathrm{H}, \mathrm{dd}, J=8,5 \mathrm{~Hz}, \mathrm{H}-5^{\prime}\right)$, dan 7,67 $(1 \mathrm{H}$, d, $\left.J=8,5 \mathrm{~Hz}, \mathrm{H}-6^{\prime}\right)$ untuk cincin B pada struktur flavonoid. Dua sinyal singlet pada geseran kimia $\delta_{\mathrm{H}}$ 6,46 dan 3,94 adalah untuk proton metin H-3 dan proton metoksi 2'- $\mathrm{OCH}_{3}$. Karakterisasi lebih lanjut dilakukan dengan membandingkan data spektrum ${ }^{1} \mathrm{H}-\mathrm{NMR}$ senyawa $\mathrm{K}_{1} \mathrm{D}_{2}\left(\mathrm{P}_{1}\right)$ dengan data dari literatur (Tabel 2) tentang senyawa flavonoid terprenilasi yang telah ditemukan sebelumnya pada spesies Artocarpus anisophyllus, yaitu 4',5-dihidroksi6,7-(2,2-dimetilpirano)-2'-metoksi-8 $\gamma, \gamma$ dimetilallilflavon (1) (Lathiff, dkk., 2015).

Tabel 2. Perbandingan data ${ }^{1} \mathrm{H}-\mathrm{NMR} \mathrm{K}_{1} \mathrm{D}_{2}$ (P1) dan senyawa flavonoid terprenilasi (1) dari literatur

\begin{tabular}{lll}
\hline Pos. & \multicolumn{1}{c}{$\bigotimes_{\mathrm{H}}(\mathrm{Jumlah} \mathrm{H}$, Multiplisitas, J dalam Hz) } \\
\cline { 2 - 3 } & \multicolumn{1}{c}{ Senyawa $\mathrm{K}_{1} \mathrm{D}_{2}(\mathrm{P} 1)$} & \multicolumn{1}{l}{ Senyawa $1^{*}$} \\
\hline 1 & - & - \\
2 & - & - \\
3 & $6,46(1 \mathrm{H}, \mathrm{s})$ & $6,76(1 \mathrm{H}, \mathrm{s})$ \\
4 & - & - \\
$4 \mathrm{a}$ & - & - \\
5 & - & - \\
6 & - & - \\
7 & - & - \\
8 & - & - \\
$8 \mathrm{a}$ & - & - \\
9 & $6,56(1 \mathrm{H}, \mathrm{d}, 16,0 \mathrm{~Hz})$ & $6,56(1 \mathrm{H}, \mathrm{d}, 16,0 \mathrm{~Hz})$ \\
10 & $6,71(1 \mathrm{H}, \mathrm{dd}, 16,0 ; 7,1 \mathrm{~Hz})$ & $6,73(1 \mathrm{H}, \mathrm{dd}, 16,0 ; 7,2 \mathrm{~Hz})$ \\
11 & $2,47(1 \mathrm{H}, \mathrm{m})$ & $2,45(1 \mathrm{H}, \mathrm{m})$ \\
$12 / 13$ & $1,10(6 \mathrm{H}, \mathrm{d}, 6,7 \mathrm{~Hz})$ & $1,09(6 \mathrm{H}, \mathrm{d}, 6,8 \mathrm{~Hz})$ \\
14 & $6,26(1 \mathrm{H}, \mathrm{d}, 9,3 \mathrm{~Hz})$ & $6,22(1 \mathrm{H}, \mathrm{d}, 9,2 \mathrm{~Hz})$ \\
15 & $5,43(1 \mathrm{H}, \mathrm{d}, 9,3 \mathrm{~Hz})$ & $5,48(1 \mathrm{H}, \mathrm{d}, 9,2 \mathrm{~Hz})$ \\
16 & - & - \\
17 & $1,97(3 \mathrm{H}, \mathrm{s})$ & $1,96(3 \mathrm{H}, \mathrm{s})$ \\
18 & $1,69(3 \mathrm{H}, \mathrm{s})$ & $1,69(3 \mathrm{H}, \mathrm{s})$ \\
$1^{\prime}$ & - & - \\
$2^{\prime}$ & - & - \\
$3^{\prime}$ & $6,42(1 \mathrm{H}, \mathrm{d}, 1,8 \mathrm{~Hz})$ & $6,44(1 \mathrm{H}, \mathrm{d}, 2,0 \mathrm{~Hz})$ \\
$4^{\prime}$ & - & - \\
$5^{\prime}$ & $6,54(2 \mathrm{H}, \mathrm{dd}, 8,5 ; 1,8 \mathrm{~Hz})$ & $6,65(1 \mathrm{H}, \mathrm{dd}, 8,4 ; 2,0 \mathrm{~Hz})$ \\
$6^{\prime}$ & $7,68(1 \mathrm{H}, \mathrm{d}, 8,5 \mathrm{~Hz})$ & $7,74(1 \mathrm{H}, \mathrm{d}, 8,4 \mathrm{~Hz})$ \\
$5-\mathrm{OH}$ & $13,42(1 \mathrm{H}, \mathrm{s})$ & $13,67(1 \mathrm{H}, \mathrm{s})$ \\
$2^{\prime}-\mathrm{OCH}$ & $3,93(3 \mathrm{H}, \mathrm{s})$ & $4,00(3 \mathrm{H}, \mathrm{s})$ \\
\hline & &
\end{tabular}

*ket: senyawa dari literatur (Lathiff, dkk., 2015) 
Pada Tabel 2 terlihat bahwa geseran kimia $\delta_{\mathrm{H}}$ senyawa $\mathrm{K}_{1} \mathrm{D}_{2}\left(\mathrm{P}_{1}\right)$ memiliki banyak kesamaan dengan senyawa (1) seperti yang telah dilaporkan oleh literatur, kecuali satu sinyal proton yang sedikit berbeda, dimana senyawa $\mathrm{K}_{1} \mathrm{D}_{2}\left(\mathrm{P}_{1}\right)$ memiliki geseran kimia $\delta_{\mathrm{H}} 6,46 \mathrm{ppm}$ sedangkan senyawa (1) 6,76 ppm pada posisi proton $\mathrm{H}-3$. Hal tersebut dimungkinkan terjadi karena adanya efek atropisomer yang terjadi antara proton $\mathrm{H}-3$ dengan proton-proton pada cincin B, khususnya proton 2'- $\mathrm{OCH}_{3}$ (Gambar 8). Fenomena ini juga membuktikan bahwa posisi gugus
$-\mathrm{OCH}_{3}$ tidak berada pada posisi orto, melainkan pada posisi meta terhadap gugus $4^{\prime}-\mathrm{OH}$ pada cincin B. Berdasarkan perbandingan data ${ }^{1} \mathrm{H}-\mathrm{NMR}$ di atas dapat disimpulkan bahwa senyawa $\mathrm{K}_{1} \mathrm{D}_{2}\left(\mathrm{P}_{1}\right)$ berwarna kuning sebanyak $5 \mathrm{mg}$ yang berhasil diisolasi dari kayu akar $A$. communis adalah $4^{\prime}, 5-$ dihidroksi-6,7-(2,2-dimetilpirano)-2'-metoksi-8 $\gamma, \gamma$ dimetilallilflavon (1), dimana senyawa tersebut telah ditemukan sebelumnya pada fraksi $n$-heksana kayu batang tumbuhan $A$. anisophyllus (Lathiff, dkk., 2015).

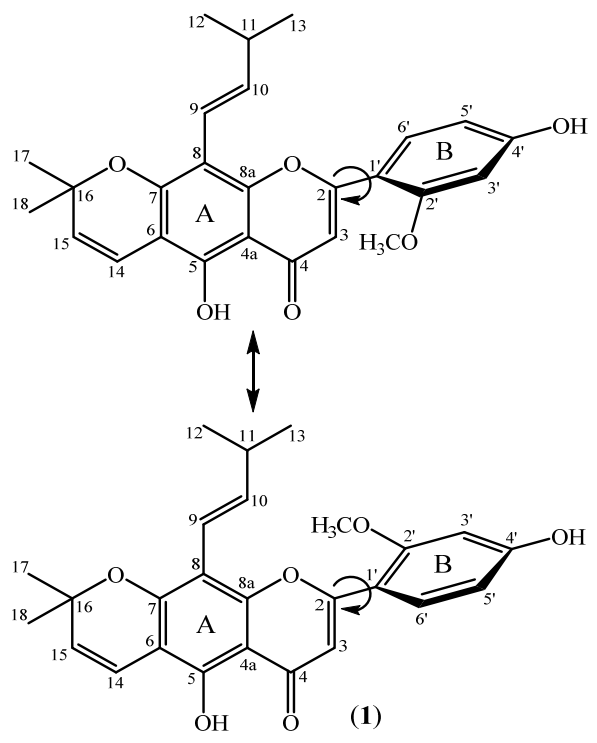

Gambar 8. Efek atropisomer cincin B akibat rotasi ikatan tunggal antara C-2 dan C-1' senyawa 1.

\section{Kesimpulan}

Senyawa $\mathrm{K}_{1} \mathrm{D}_{2}\left(\mathrm{P}_{1}\right)$ yang diisolasi adalah $4^{\prime}, 5-$ dihidroksi-6,7-(2,2-dimetilpirano)-2'-metoksi$8 \gamma, \gamma$-dimetilallilflavon (1).

\section{Ucapan Terima Kasih}

Ucapan terima kasih penulis sampaikan kepada Prof. Yana Maolana Syah dan Dr. Elvira Hermawati dari Departemen Kimia ITB yang telah menganalisis senyawa 1 dengan spektrometer NMR

\section{Referensi}

Adewole, S. O., \& Ojewole, J. A. (2007). Hyperglicaemic effect of artocarpus communis forst (moraceae) root bark aquoeus extract in wistar rats. Cardiovascular Journal of Africa, 18(4), 221-227.

Arung, E. T., Wicaksono, B. D., Handoko, Y. A., Kusuma, I. W., Yulia, D., \& Sandra, F. (2009). Anti-cancer properties of diethylether extract of wood from sukun (artocarpus altilis) in human breast cancer (t47d) cells. Tropical
Journal of Pharmaceutical Research, 8(4), 317 324.

Chan, S. C., Ko, H. H., \& Lin, C. N. (2003). New prenylflavonoids from Artocarpus communis. Journal of Natural Products, 66(3), 427-430.

Erwin. (2010). Profil kimia artocarpus (the chemical profile of artocarpus). Jurnal Kimia Mulawarman, 8(1), 54-62.

Hakim, A. (2010). Diversity of secondary metabolites from genus artocarpus (moraceae). Nusantara Bioscience, 2(3), 146-156.

Hakim, E. H., Marlina, E. E., Mujahidin, D., Achmad, S. A., Ghisalberti, E. L., \& Hakim, L. (1998). Artocarpin dan heteroflavanon-a, dua senyawa flavonoid bioaktif dari artocarpus chempeden. PROC. ITB, 30(1), 31-36.

Harborne, J. B. (1987). Metode fitokimia penentuan cara modern menganalisis tumbuhan. Bandung: ITB Bandung. 
Hariana, A. (2006). Tumbuhan obat dan khasiatnya seri 3. Jakarta: Penebar Swadaya.

Heyne, K. (1987). Tumbuhan berguna indonesia, jilid II. Jakarta: Badan Litbang Kehutanan.

Hsu, C. L., Chang, F. R., Tseng, P. Y., Chen, Y. F., Shazly, M. E., Du, Y. C., \& Fang, S. C. (2012). Geranyl flavonoid derivatives from the fresh leaves of artocarpus communis and their anti-inflammatory activity. Planta Medica, 78, 995-1001.

Jagtap, U. B., \& Bapat, V. A. (2010). Artocarpus: A review of its traditional uses, phytochemistry and pharmacology. Ethnopharmacology, 129, 143-144.

Kristanti, H., \& Tunjung, W. A. S. (2015). Detection of alkaloid, flavonoid, and terpenoid compounds in bread (artocarpus communis forst.) leaves and pulps. KnE Life Sciences, 2, 129-133.

Kuete, V., Patrick, Y. A., Ghislain, W. F., Gilbert, D. W. F. K., Jean, P. D., Arlette, G. W., Bonaventure, T. B. \& Berhanu, M. A. (2011). Antimicrobial activities of the methanol extract and compounds from artocarpus communis (moraceae). BMC
Complementary and Alternative Medicine, 11(42), 1-5.

Lathiff, S. M. A., Jemaon, N., Abdullah, S. A. \& Jamil, S. (2015). Flavonoids from Artocarpus anisophyllus dan their bioactivities. Natural Product Communications, 10(3), 393-396.

Lin, K. W., Liu, C. H., Tu, H. Y., Ko, H. H., \& Wei, B. L. (2009). Antioxidant prenylflavonoids from artocarpus communis and artocarpus elasticus. Food Chemistry. $115,558-562$.

Toume, K., Tadashi, H., Midori, A. A., Takashi, K., Thaworn, K., \& Masami, I. (2014). Prenylated flavonoids and resveratrol derivatives isolated from artocarpus communis with the ability to overcome trail resistance. Journal of Natural Products, 78(1), 1-8.

Tzeng, C. W., Yen, F. L., Lin, L. T., Lee, C. W., Yen, M. H., Tzeng, W. S., \& Lin, C. C. (2014). Antihepatoma activity of artocarpus communis is higher in fractions with high artocapin content. The Scientific World Journal, 1-8. 